\title{
Epirubicin sequential natural killer cells enhanced the cytotoxicity to breast cancer cells in vitro
}

\author{
Yanqiu Song ${ }^{1}$, Qian Wang ${ }^{1}$, Hui Feng ${ }^{1}$, Ying Dong ${ }^{1}$, Jingtao Chen ${ }^{2 *}$ \\ From 30th Annual Meeting and Associated Programs of the Society for Immunotherapy of Cancer (SITC 2015) \\ National Harbor, MD, USA. 4-8 November 2015
}

\section{Background}

Anthracycline-based chemotherapy is a conventional therapy for breast cancer patients, but also negatively affects host immune function. When the host immune system does not work, chemotherapy and radiotherapy cannot kill the cancer cells efficiently. Therefore, improve the host immune system is important for cancer efficient treatment. Meanwhile, natural killer (NK) cells are well known to boost the immune responses against cancer.

\section{Methods}

In this study, breast cancer cell lines were treated with anthracycline agent epirubicin (EPI) sequential with immune cells NK. NK cells in the study were amplified for 14 days in vitro from autologous adoptive cell transfer of breast cancer patients.

\section{Results}

The cytotoxicity of NK cells against breast cancer cells with $12 \mathrm{hr}$ EPI $(5.0 \mu \mathrm{g} / \mathrm{ml})$ pre-treatment was significantly higher than untreated or EPI alone. Thus, EPI sequential NK cells show the synergistic cytotoxicity effects against breast cancer cells. Moreover, breast cancer cells show increased expression of NKG2D ligands (ULBP1, ULBP2 and MICA) after treatment of EPI. Additionally, EPI sequential NK cells secret more IFN- $\gamma$ and TNF- $\alpha$ as well as the increased expression of perforin and Granzyme B.

\section{Conclusions}

Our findings reveal possible evidence for how to combine anthracycline-based chemotherapy with NK cells biotherapy to make a better treatment.

${ }^{2}$ Institute of Translational Medicine, The First Hospital, Jilin University, Changchun, 130061, Jilin, China

Full list of author information is available at the end of the article
Authors' details

${ }^{1}$ Cancer Center, The First Hospital, Jilin University, Changchun, 130061, Jilin, China. ${ }^{2}$ Institute of Translational Medicine, The First Hospital, Jilin University, Changchun, 130061, Jilin, China.

Published: 4 November 2015

doi:10.1186/2051-1426-3-S2-P6

Cite this article as: Song et al:: Epirubicin sequential natural killer cells enhanced the cytotoxicity to breast cancer cells in vitro. Journal for ImmunoTherapy of Cancer 2015 3(Suppl 2):P6.
Submit your next manuscript to BioMed Central and take full advantage of:

- Convenient online submission

- Thorough peer review

- No space constraints or color figure charges

- Immediate publication on acceptance

- Inclusion in PubMed, CAS, Scopus and Google Scholar

- Research which is freely available for redistribution
() Biomed Central 